\title{
Vasopressin $\mathrm{V} 1$ receptor-mediated aldosterone production as a result of selective $\mathbf{V} 2$ receptor antagonism: a potential explanation for the failure of tolvaptan to reduce cardiovascular outcomes in the EVEREST trial
}

\author{
Bertram Pitt ${ }^{1 *}$ and Mihai Gheorghiade ${ }^{2}$ \\ ${ }^{1}$ University of Michigan School of Medicine, Cardiovascular Center, 1500 E. Medical Center Dr., Ann Arbor, MI 48109, USA; and ${ }^{2}$ Center for Cardiovascular Innovation, \\ Northwestern University Feinberg School of Medicine, 645 North Michigan Ave., Suite 1006, Chicago, IL 60611, USA
}

Plasma volume expansion in patients with heart failure (HF) is associated with neurohumeral activation; symptom and signs of pulmonary congestion and peripheral oedema; an increase in hospitalizations for HF; and cardiovascular mortality. ${ }^{1}$ A reduction in plasma volume, as evidenced by haemoconcentration, has recently been suggested to be associated with an improvement in cardiovascular mortality. ${ }^{2}$ However, while loop diuretics reduce plasma volume and relieve the symptoms and signs of pulmonary congestion, they activate the renin-angiotensin-aldosterone system (RAAS) and, in experimental studies $^{3}$ and some, although not all, retrospective clinical studies have been associated with an increase in cardiovascular mortality. ${ }^{4,5}$ Due to the controversy associated with the use of high-dose loop diuretics and their effect on cardiovascular mortality in patients with HF and a reduced left ventricular ejection fraction (REF) there has been increasing interest in alternative and or supplemental diuretic strategies to reduce plasma volume and to improve cardiovascular outcomes in patients with HFREF.

Tolvaptan, a selective V2 vasopressin antagonist, has been shown in pre-clinical and short-term studies in patients with $\mathrm{HF}$ to be a potent aquaretic with a resultant increase in urine output; a decrease in body weight; a decrease in pulmonary capillary wedge pressure; an increase in serum sodium concentration; without activation of the RAAS. ${ }^{6}$ However when studied over the longer term in patients with HFREF, it has not been shown to reduce natriuretic peptide levels or left ventricular remodelling, ${ }^{7,8}$ and did not improve cardiovascular outcomes despite an early improvement in symptoms of dyspnoea, a prolonged reduction in body weight, and normalization of serum sodium in hyponatraemic patients. ${ }^{8,9}$ The finding that tolvaptan failed to reduce natriuretic peptide levels and cardiovascular outcomes despite a reduction in body weight is especially notable since an increase in body weight post-discharge is the single most important predictor for readmission in patients with heart failure and a major predictor of mortality. ${ }^{10}$ The explanation for the failure of tolvaptan to improve ventricular remodelling, natriuretic peptide levels, and cardiovascular outcomes despite a reduction in body weight remains uncertain. Several explanations have, however, been proposed, including the suggestion that the dose of tolvaptan $(30 \mathrm{mg} /$ day $)$ may have been inadequate; that patients selected for study did not have hyponatraemia; and the possibility that a reactive increase in vasopressin levels might over the long term stimulate the $\mathrm{V} 1 \mathrm{a}$ receptor with a resultant increase in vasoconstriction, which might negate the beneficial effects associated with aquareses. ${ }^{6,11}$ Without further prospective mechanistic studies it is difficult to confirm or refute these explanations. Recently, however, it has been shown that a deficiency of the $\mathrm{V} 1 \mathrm{a}$ receptor causes hyporeninaemic hypoaldsteronism, ${ }^{12}$ and stimulation of the $\mathrm{V} 1 \mathrm{a}$ receptor causes the adrenal production of aldosterone. ${ }^{13}$ The V1a receptor also affects the renal tubular effects of aldosterone. ${ }^{14} \mathrm{We}$ postulate that these findings may explain the paradox of a persistent reduction in body weight despite the lack of an improvement in natriuretic peptide levels and cardiovascular outcomes associated with the use of tolvaptan in EVEREST. ${ }^{11}$ This hypotheses and its implications for the therapy of patients with HF will be briefly discussed below.

As noted above, $\mathrm{V} 2$ receptor antagonism results in a sustained reduction in body weight along with an early transient decrease in pulmonary capillary wedge pressure ${ }^{15}$ without activation of the RAAS. ${ }^{16}$ However, over the long term there is a reactive increase in vasopressin levels, ${ }^{6,17}$ with a resultant increased activation of the unprotected $\mathrm{V} 1 \mathrm{a}$ receptor in the myocardium and vascular wall. This increase in vasopressin levels in patients receiving tolvaptan has recently been associated with an increase in aldosterone levels. ${ }^{17}$ 
In patients with HF there is an up-regulation of the mineralocorticoid receptor (MR) in the myocardium ${ }^{18}$ and macrophages, ${ }^{19}$ along with an increase in plasma aldosterone levels. ${ }^{20}$ Aldosterone and activation of the MR decrease antioxidant reserves, increase reactive oxygen species (ROS), ${ }^{21}$ increase inflammatory cytokine activation, ${ }^{22}$ increase tissue angiotensin-converting enzyme (ACE) and angiotensin type 1 receptor (AT1R) expression, ${ }^{23}$ increase the levels of plasminogen activator-1 (PAl-1) levels, ${ }^{24}$ stimulate reactive myocardial and perivascular fibrosis, decrease nitric oxide availability, increase endothelial dysfunction, increase myocardial cell death, and reduce endothelial progenitor cell production and vascular repair. ${ }^{25}$ Thus it can be postulated that over the long term the beneficial effects of $\mathrm{V} 2$ receptor antagonism may be negated by $\mathrm{V} 1 \mathrm{a}$ receptor stimulation with subsequent production of aldosterone, MR activation, sodium retention, and a tendency to increase plasma volume which could offset the reduction in plasma volume resulting from blockade of the V2 receptor and aquareses.

There are several implications of our hypotheses both for the further evaluation of vasopressin antagonists and for the therapy of patients with HF. The combination of a V2 receptor antagonist and an MR antagonist (MRA) might be of interest especially in patients with acute decompensated HF (ADHF). The current dose of the MRAs spironolactone $25-50 \mathrm{mg}$ and eplerenone 25-50 mg, while effective in reducing total mortality and hospitalizations in patients with chronic HFREF, ${ }^{26}$ are only mildly diuretic. Prior to the RALES study, ${ }^{27}$ a dose of spironolactone $100-200 \mathrm{mg}$ day was suggested to be beneficial in overcoming diuretic resistance in patients with $A D H F{ }^{28}$ The increased levels of aldosterone in patients receiving a $\mathrm{V} 2$ receptor antagonist might require these higher doses of MRAs to block the MR and to achieve diuresis. The combination of a $\mathrm{V} 2$ receptor selective antagonist and a high dose MRA could provide an increase in urinary output, an increase in sodium excretion, and a decrease in plasma volume, while preventing the activation of the MR with its adverse consequences. The safety of this approach will, however, require prospective evaluation. One might also consider the combination of a V2 receptor selective antagonist with a natriuretic peptide. For example, Costello-Boerrrigter et al. ${ }^{29}$ have shown that tolvaptan alone increases systemic vascular resistance, blood pressure, and aldosterone levels. However, with the combination of tolvaptan plus brain natriuretic peptide (BNP) there is no increase in systemic vascular resistance, blood pressure, or aldosterone levels but an increase in urinary sodium excretion. Conversely, one might consider the use of a non-selective $\mathrm{V} 1-\mathrm{V} 2$ vasopressin receptor antagonist alone, which would not be expected to increase aldosterone levels above the level associated with the severity of heart failure. However, in view of the increase in aldosterone levels in patients with HF independent of the long-term use of a $V 2$ receptor antagonist, it might be useful to consider a combination of a non-selective $\mathrm{V} 1-\mathrm{V} 2$ antagonist in conjunction with an MRA or natriuretic peptide such as BNP. Clearly, although the selective $\mathrm{V} 2$ receptor antagonist tolvaptan has not been shown to reduce cardiovascular outcomes in patients with heart failure, ${ }^{8}$ further investigation of the combination of a $\mathrm{V} 2$ receptor antagonist and an MRA or natriuretic peptide such as BNP and.or the use of a non-selective $\mathrm{V} 1-2$ receptor antagonist alone or in conjunction with an MRA or natriuretic peptide holds the promise of a reduction in cardiovascular outcomes in patients with acute and chronic heart failure.

Conflict of interest: B.P. is a consultant for Pfizer, Merck, Novartis, Bayer, Takeda, and Astra Zeneca. M.G. is a consultant for Otsuka, Solvay Pharma, Novartis, Bayer, Sigma Tau, Debiopharm, Medtronic, Merck, Astellas, Cytokinetics CoThera, Inc., Pericor Therapeutics, GlaxoSmithKline, Johnson \& Johnson, Abbott, Errekappa Terapeutici, Protein Design Laboratories, AstraZenica, and Sanofi Aventis.

\section{References}

1. Gheorghiade M, Follath F, Ponikowski P, Barsuk JH, Blair JE, Cleland JG, Dickstein K, Drazner MH, Fonarow GC, Jaarsma T, Jondeau G, Sendon JL, Mebazaa A, Metra M, Nieminen M, Pang PS, Seferovic P, Stevenson LW, van Veldhuisen DJ, Zannad F, Anker SD, Rhodes A, McMurray JJ, Filippatos G. Assessing and grading congestion in acute heart failure: a scientific statement from the acute heart failure committee of the heart failure association of the European Society of Cardiology and endorsed by the European Society of Intensive Care Medicine. Eur J Heart Fail 2010;12:423-433.

2. Ling H, Aung N, Flint J, Aggarwal S, Cheng A, Thomas M, Woldman S, Okonko D. Calculated plasma volume status and mortality in chronic heart failure. J Am Coll Cardiol 2011;57:pE370.

3. McCurley JM, Hanlon SU, Wei SK, Wedam EF, Michalski M, Haigney MC. Furosemide and the progression of left ventricular dysfunction in experimental heart failure. J Am Coll Cardiol 2004;44:1301-1307.

4. Domanski M, Norman J, Pitt B, Haigney M, Hanlon S, Peyster E. Diuretic use, progressive heart failure, and death in patients in the Studies Of Left Ventricular Dysfunction (SOLVD). J Am Coll Cardiol 2003;42:705-708.

5. Hasselblad V, Gattis Stough W, Shah MR, Lokhnygina Y, O'Connor CM, Califf RM, Adams KF Jr. Relation between dose of loop diuretics and outcomes in a heart failure population: results of the ESCAPE trial. Eur J Heart Fail 2007;9:1064-1069.

6. Lee CR, Watkins ML, Patterson JH, Gattis W, O'Connor CM, Gheorghiade M, Adams KF Jr. Vasopressin: a new target for the treatment of heart failure. Am Heart J 2003;146:9-18.

7. Udelson JE, McGrew F, Flores E, al. E. Multicenter, randomized, double-blind, placebo-controlled study on the effect of oral tolvaptan on left ventricular dilation and function in patients with heart failure and systolic dysfunction. J Am Coll Cardiol 2007;49:2151-2159.

8. Konstam MA, Gheorghiade M, Burnett JC Jr, Grinfeld L, Maggioni AP, Swedberg K, Udelson JE, Zannad F, Cook T, Ouyang J, Zimmer C, Orlandi C. Effects of oral tolvaptan in patients hospitalized for worsening heart failure: the EVEREST outcome trial. JAMA 2007;297:1319-1331.

9. Zmily HD, Daifallah S, Ghali JK. Tolvaptan, hyponatremia, and heart failure. Int J Nephrol Renovasc Dis 2011;4:57-71.

10. Blair JE, Khan S, Konstam MA, Swedberg K, Zannad F, Burnett JC Jr., Grinfeld L, Maggioni AP, Udelson JE, Zimmer CA, Ouyang J, Chen CF, Gheorghiade M. Weight changes after hospitalization for worsening heart failure and subsequent re-hospitalization and mortality in the EVEREST trial. Eur Heart J 2009;30: 1666-1673.

11. Konstam MA, Udelson JE. Hyponatraemia and vasopressin in heart failure: markers or mediators? Eur J Heart Fail 2011;13:242-244.

12. Aoyagi T, Izumi Y, Hiroyama M, Matsuzaki T, Yasuoka Y, Sanbe A, Miyazaki H, Fujiwara Y, Nakayama Y, Kohda Y, Yamauchi J, Inoue T, Kawahara K, Saito H, Tomita K, Nonoguchi H, Tanoue A. Vasopressin regulates the reninangiotensin-aldosterone system via v1a receptors in macula densa cells. Am J Physiol Renal Physiol 2008;295:F100-F107.

13. Izumi Y, Hori K, Nakayama Y, Kimura M, Hasuike Y, Nanami M, Kohda Y, Otaki Y, Kuragano T, Obinata M, Kawahara K, Tanoue A, Tomita K, Nakanishi T, Nonoguchi $H$. Aldosterone requires vasopressin v1a receptors on intercalated cells to mediate acid-base homeostasis. J Am Soc Nephrol 2011;22:673-680.

14. Tashima Y, Kohda Y, Nonoguchi H, Ikebe M, Machida K, Star RA, Tomita K. Intranephron localization and regulation of the v1a vasopressin receptor during chronic metabolic acidosis and dehydration in rats. Pflugers Arch 2001;442: 652-661.

15. Udelson JE, Orlandi C, Ouyang J, Krasa H, Zimmer CA, Frivold G, Haught WH, Meymandi S, Macarie C, Raef D, Wedge P, Konstam MA, Gheorghiade M. Acute hemodynamic effects of tolvaptan, a vasopressin $v 2$ receptor blocker, in patients with symptomatic heart failure and systolic dysfunction: an international, multicenter, randomized, placebo-controlled trial. J Am Coll Cardiol 2008;52: $1540-1545$. 
16. Veeraveedu PT, Watanabe K, Ma M, Palaniyandi SS, Yamaguchi K, Kodama M, Aizawa $Y$. Effects of v2-receptor antagonist tolvaptan and the loop diuretic furosemide in rats with heart failure. Biochem Pharmacol 2008;75:1322-1330.

17. Gheorghiade M, Pang PS, Ambrosy AP, Lan G, Schmidt P, Filippatos G, Konstam M, Swedberg K, Cook T, Traver B, Maggioni A, Burnett J, Grinfeld L, Udelson J, Zannad F. A comprehensive, longitudinal description of the in-hospital and post-discharge clinical, laboratory, and neurohormonal course of patients with heart failure who die or are re-hospitalized within 90 days: analysis from the EVEREST trial. Heart Fail Rev 2011;in press.

18. Yoshida M, Ma J, Tomita T, Morikawa N, Tanaka N, Masamura K, Kawai Y, Miyamori I. Mineralocorticoid receptor is overexpressed in cardiomyocytes of patients with congestive heart failure. Congest Heart Fail 2005;11:12-16.

19. Usher MG, Duan SZ, Ivaschenko CY, Frieler RA, Berger S, Schutz G, Lumeng CN, Mortensen RM. Myeloid mineralocorticoid receptor controls macrophage polarization and cardiovascular hypertrophy and remodeling in mice. J Clin Invest 2010; 120:3350-3364.

20. Guder G, Bauersachs J, Frantz S, Weismann D, Allolio B, Ertl G, Angermann CE, Stork S. Complementary and incremental mortality risk prediction by cortisol and aldosterone in chronic heart failure. Circulation 2007;115:1754-1761.

21. Leopold JA, Dam A, Maron BA, Scribner AW, Liao R, Handy DE, Stanton RC, Pitt B, Loscalzo J. Aldosterone impairs vascular reactivity by decreasing glucose-6phosphate dehydrogenase activity. Nat Med 2007;13:189-197.
22. Rocha R, Funder JW. The pathophysiology of aldosterone in the cardiovascular system. Ann NY Acad Sci 2002;970:89-100.

23. Schiffrin EL. Effects of aldosterone on the vasculature. Hypertension 2006;47: 312-318.

24. Brown NJ, Nakamura S, Ma L, Nakamura I, Donnert E, Freeman M, Vaughan DE, Fogo $A B$. Aldosterone modulates plasminogen activator inhibitor-1 and glomerulosclerosis in vivo. Kidney Int 2000;58:1219-1227

25. Pitt B. Plasma aldosterone levels in patients with coronary artery disease without heart failure or myocardial infarction: implications for pathophysiology, prognosis, and therapy. Eur Heart J 2011; in press.

26. Zannad F, McMurray J], Krum H, van Veldhuisen DJ, Swedberg K, Shi H, Vincent J, Pocock SJ, Pitt B. Eplerenone in patients with systolic heart failure and mild symptoms. N Engl J Med 2011;364:11-21.

27. Pitt B, Zannad F, Remme WJ, Cody R, Castaigne A, Perez A, Palensky J, Wittes J. The effect of spironolactone on morbidity and mortality in patients with severe heart failure. Randomized aldactone evaluation study investigators. N Engl J Med 1999;341:709-717.

28. van Vliet A, Donker A, Nauta J, Verheugt FW. Spironolactone in congestive heart failure refractory to high-dose loop diuretic and low-dose angiotensin-converting enzyme inhibitor. Am J Cardiol 1993;71:21A-28A.

29. Costello-Boerrigter LC, Boerrigter G, Cataliotti A, Harty GJ, Burnett JC Jr. Renal and anti-aldosterone actions of vasopressin-2 receptor antagonism and B-type natriuretic peptide in experimental heart failure. Circ Heart Fail 2010;3:412-419. 